九州大学学術情報リポジトリ

Kyushu University Institutional Repository

Impact of Synchronizing the Application of

Different Biochar Organic Fertilisers with NPK on Soil Chemical Properties and Growth of Leek (Allium ampeloprasum)

LUYIMA, Deogratius

Department of Bio-Environmental Chemistry, Chungnam National University

LEE, Jae-Han

Department of Bio-Environmental Chemistry, Chungnam National University

AN, Ji-Young

Department of Bio-Environmental Chemistry, Chungnam National University

KWON, Oh-Seok

Department of Bio-Environmental Chemistry, Chungnam National University

他

https://doi.org/10.5109/2231633

出版情報：九州大学大学院農学研究院紀要. 64 (1)，pp.47-53，2019-02-28. Faculty of Agriculture， Kyushu University

バージョン :

権利関係 : 


\title{
Impact of Synchronizing the Application of Different Biochar Organic Fertilisers with NPK on Soil Chemical Properties and Growth of Leek (Allium ampeloprasum)
}

\author{
Deogratius LUYIMA ${ }^{1, \dagger}$, Jae-Han LEE ${ }^{1, \dagger}$, Ji-Young AN ${ }^{1}$, Oh-Seok KWON ${ }^{1}$, Sang-Yeon PARK ${ }^{1}$, \\ Su-Jin LEE ${ }^{1}$, Seong-Yong PARK ${ }^{1}$, Yoshiyuki SHINOGI, \\ Kee Woong PARK ${ }^{2, *}$ and Taek-Keun $\mathrm{OH}^{1, *}$
}

Science for Bioproduction Environment, Faculty of Agriculture, Kyushu University, Fukuoka 819-0395, Japan

(Received October 31, 2018 and accepted November 12, 2018)

\begin{abstract}
Biochar is a popular organic soil amendment around the world. However, some factors still hinder its full agronomic potentials including low nutrient concentrations especially of aromatic biochar charred from nutrient-poor biomass. Improving the nutrient quality of this type of biochar may necessitate its combined application with organic and or inorganic fertilisers. This study, therefore, aimed to explore the synergistic effects of synchronizing the addition of biochar organic fertilisers with NPK on soil chemical properties and the growth and yield of leek (Allium ampeloprasum). A pot experiment with soil amendments constituting six treatments was conducted. The treatments included; the non-amended control, NPK fertiliser, CLB + NPK, CLB alone, NPOM + NPK, NPOM alone. CLB was made by mixing 80\% livestock compost and 20\% oak biochar. NPOM was made by pelletizing a mixture of 30\% oak biochar, $50 \%$ castor bean expeller cake, 10\% used coffee grounds and $10 \%$ rice bran. The oak biochar was pyrolysed for 3 hours at $600^{\circ} \mathrm{C}$. Each of the biochar organic fertiliser was added to the soil at a rate of $2 \%$ (15 tonnes per hectare, considering a depth of incorporation of $5 \mathrm{~cm}$ with a bulk density of $1000 \mathrm{~kg} \mathrm{~m}^{-3}$ ). The results of the synchronized applications varied between the two organic fertilisers. CLB + NPK showed synergistic effects both in amelioration of soil chemical properties and leek growth and yield while NPOM + NPK elicited adverse effects on leek growth and yield. In conclusion, combined application of NPK and biochar organic fertilisers may or may not have synergistic effects depending on the characteristics of the biochar organic fertiliser used.
\end{abstract}

Key words: Biochar and NPK, Synchronised soil application, biochar organic fertilisers, Leek

\section{INTRODUCTION}

The rapidly growing global population means that the cultivable land area is reducing (Shahid et al., 2011) amidst skyrocketing food demand (FAO 2006a; Müller, 2009). Needless to say, soil productivity is on a rapid decline (Naeem et al., 2018). The decline in soil quality hasmainly been agitated by intensive cultivation and changes in agro-climatic conditions (Naeem et al., 2018) and is likely to exacerbate hunger, food insecurity and rural poverty. Although chemical fertilisers are highly credited for amplifying agricultural productivity during the green revolution (Gruhn et al., 2000), their upper limit seems surpassed right now as evidenced by increasing reports of no, or low yield increases from fields where these inorganic fertilisers have been used alone (Jones et al., 2013). Maintenance of appropriate organic matter levels is key to improving soil quality and crop yields (Palm, et al., 2001; Liu et al., 2010). Nutrient management in agricultural land, such as continuous application of organic matter, improved fertilizer utilization efficiency

Department of Bio-Environmental Chemistry, Chungnam National University, Daejeon 34134, Korea

2 Department of Crop Science, Chungnam National University, Daejeon 34134, Korea

$\dagger$ These two authors contributed equally to this work and should be considered co-first authors

* Corresponding author (E-mail: ok5382@cnu.ac.kr) (T.K. OH)

* Corresponding author (E-mail: parkkw@cnu.ac.kr (K.W. Park) and minimization of soil nutrient loss, are good ways to increase organic carbon content in the soil (Lee, 2013; Lee et al., 2016). Composts and manures including mulches have for a long time been used to recycle plant nutrients as well as building soil organic matter stocks (Liu et al., 2010). However, the benefits accruing from many of such soil amendments usually have transient effects in the soil (Naeem et al., 2018), thanks to their high decomposition rates rapidly oxidising the added organic matter to carbon dioxide (Bol, 2000).

Owing to its association with increasing greenhouse gas levels in the atmosphere, global climate change has highlighted the importance of organic carbon storage, particularly in soil (Han et al., 2016). Biochar, a solid carbonaceous material that is produced by pyrolyzing biomass under limited oxygen conditions (Oh and Shinogi, 2013; Sohi, 2012), has emerged as a promising carbon isolation measure (Lehmann and Joseph, 2015). And, it semi-permanently sequesters carbon in the soil, biochar is considered to be an effective soil amendment. (Oh et al., 2014; Oh et al., 2017). Addition of recalcitrant biochar into the soil has proved to have long lasting positive effects on soil quality through the improvement of chemical, physical, biological and ecological properties of the soil (Jien and Wang, 2013; Lin et al., 2016; Ding et al., 2016) while acting as a sink for the carbon that would otherwise cause havoc in the earth's atmosphere (Malghani et al., 2013). However, the nutrient content of biochar largely depends on the feedstock type and the conditions of the pyrolysis process. In this regard, when 
biochar produced by fast pyrolysis from lignocellulosic biomass is added to soil, organic or chemical fertilisers are still needed to improve crop yield (Kim et al, 2014) due to the low nutrient content of such biochars. A number of studies have revealed that blending lingo cellulosic biochars with nutrient-rich animal manures, compost (Hua et al., 2009; Ro et al, 2010) or even fresh organic materials (Bonanomi et al., 2017) before incorporation into the soil adds value to the biochar. Liu et al. (2012) indicated that applying compost in combination with biochar had a synergistic, positive effect on soil organic matter (SOM) content, nutrient concentrations in soil and soil water-holding capacity under field conditions. Hence, there is an increasing interest in integrating different approaches in the quest to improve soil fertility and crop productivity (Akhtar et al., 2015).

This study was therefore aimed at exploring the synergistic effects of two biochar organic fertiliser types and their combinations with NPK fertiliser on soil chemical properties and growth of leek (Allium ampelopra- sum). The biochar organic fertilisers included NPOM (containing $70 \%$ of non pyrolysed materials) and CLB (containing 20\% powdered biochar added to 80\% of compost).

\section{MATERIALS AND METHODS}

\section{Biochar production and its nutrient composition}

Oak biochar pyrolysed at $600^{\circ} \mathrm{C}$ for 3 hours was finely crushed. $30 \%$ of the finely crushed biochar was mixed with $70 \%$ of non pyrolysed organic materials and then pelletized (NPOM). The second biochar organic fertiliser type was produced by mixing $20 \%$ of finely crushed biochar with $80 \%$ of composted livestock manure (CLB). The NPOM was made by the use of a locally fabricated biochar pellet machine sps 200 model (manufactured by Gumgang engineering). The non pyrolysed organic materials used in the production of NPOM included 10\% of used coffee grounds collected from coffee shops, 50\% of castor bean expeller cake obtained from a local oil pro-

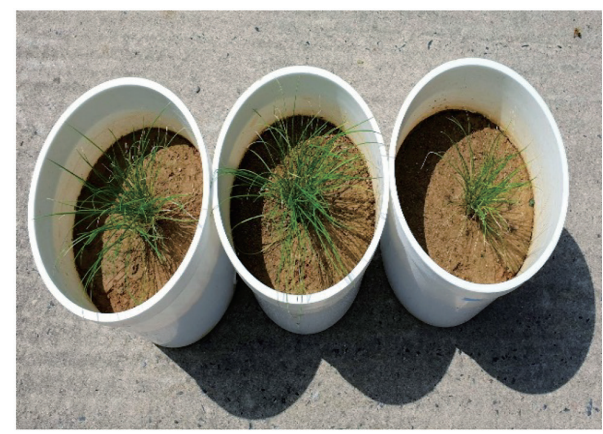

Control Experiment

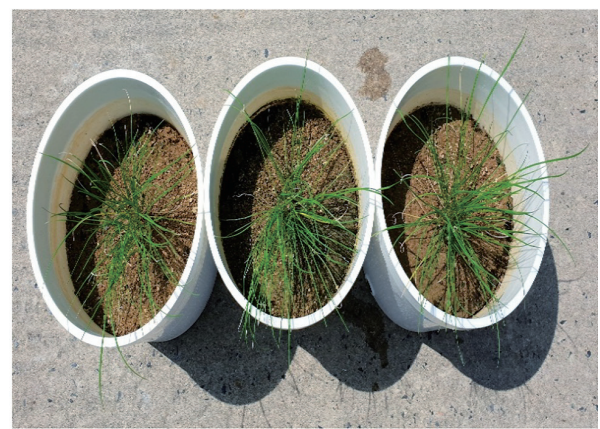

CLB alone

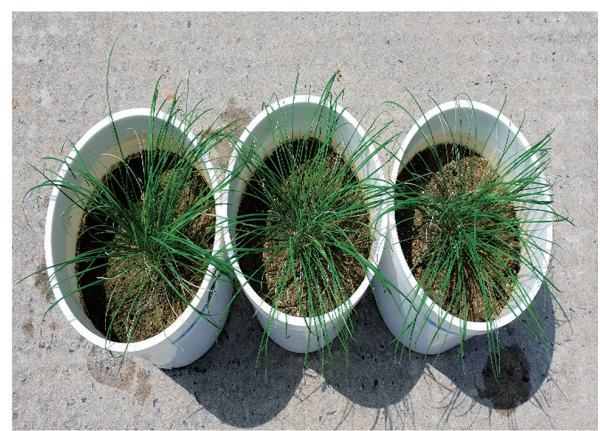

NPOM alone

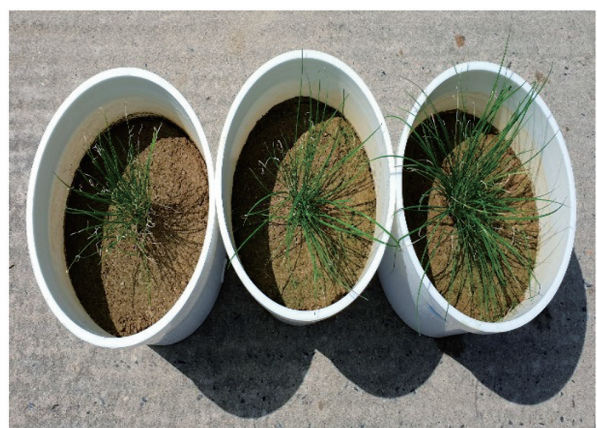

NPK Fertiliser alone

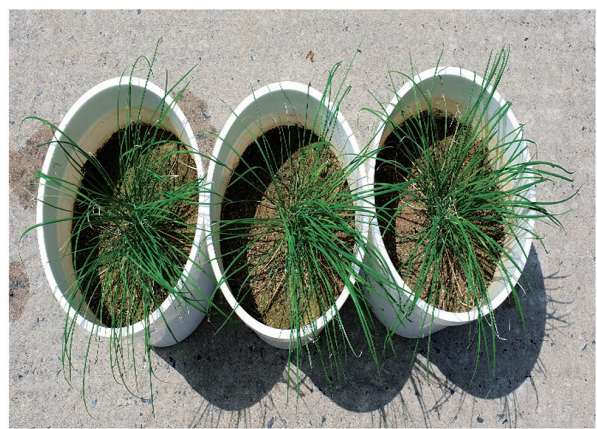

CLB + NPK Fertiliser

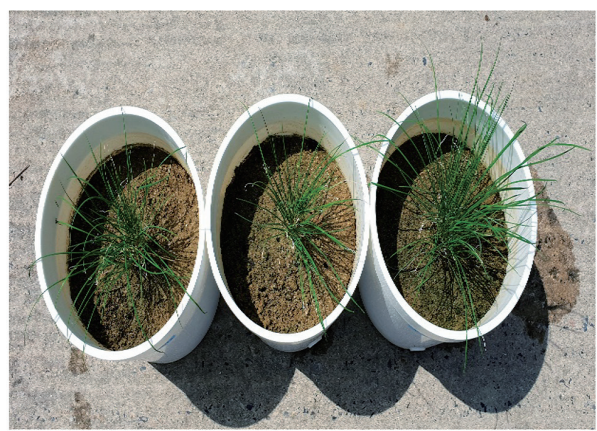

NPOM + NPK Fertiliser

Fig. 1. Leek grown on different soil amendments. 
cessing unit and $10 \%$ of rice bran also from a local rice processing plant.

\section{Laboratory analysis of Biochar and Soil Samples}

Biochar and soil samples were prepared and analysed in accordance with the analytical methods for soil, water quality and liquid fertilisers (NAAS, 2013). pH and electrical conductivity (EC)were measured with a $\mathrm{pH}$ and EC meter (ORION Versa Star Pro; Thermo Scientific, Inc., USA) after extraction with distilled water in a ratio of 1:5 (v/w), exchangeable cations including $\left(\mathrm{K}^{+}, \mathrm{Ca}^{2^{+}}\right.$, $\mathrm{Mg}^{2+}, \mathrm{Na}^{+}$) were analysed with the help of inductively coupled plasma optical emission spectrometry (ICPOES; GBC Scientific, Australia) after leaching with $1 \mathrm{~N}$ $\mathrm{NH}_{4} \mathrm{OA}_{\mathrm{c}}$ solution with a neutral $\mathrm{pH}(\mathrm{pH}$ 7.0). Total organic carbon, nitrogen and organic matter content (OM) were analysed with a $\mathrm{CN}$ analyser (Eager 300; Thermo Scientific, Inc.), available (P) by the Lancaster method using a UV-VIS spectrophotometer (Evolution 300; Thermo Scientific, Inc.). Biochar total element concentration ( $\mathrm{K}, \mathrm{Ca}, \mathrm{Mg}, \mathrm{Na}$ ) was assessed with ICP (Icap 7000Thermo Scientific, Inc.).

\section{Study site and experimental design}

A pot experiment using 2000/1a Wagner pots arranged in a complete randomised block design (CRBD) placed inside a greenhouse at Chungnam National University research farm, Korea. The six treatments included; the non-amended control, NPOM + NPK fertiliser, CLB + NPK fertiliser, NPK fertiliser, NPOM and CLB. Each treatment was replicated three times. The Soil utilised in this experiment was obtained from Charm Grow, a local Korean fertiliser research company. The soil was sifted through a $5-\mathrm{mm}$ sieve and about $14 \mathrm{~kg}$ of the sifted soil were weighed and put in each of the Wagner pots. Leek seedlings were transplanted and grown in the Wagner pots. Both NPOM and CLB were applied to the soil at a rate of $2 \%$ i.e. 20 grams for every $1 \mathrm{~kg}$ of soil used (15 tonnes per hectare, considering a depth of incorporation of $5 \mathrm{~cm}$ with a bulk density of $1000 \mathrm{~kg} \mathrm{~m}^{-3}$ ). NPK was added at rates recommended by the Rural Development Administration (RDA) of the ministry of Agriculture, Food and rural affairs of South Korea.

\section{Characteristics and growth parameters of leek}

Super green belt variety of leek whose seedlings were bought from Asian seed company, a local seed company was utilised in this study. The crops were supplied with adequate water to ensure proper growth and development. The growth parameters used to analysethe effects of different biochar types on the productivity of leek included; width and length of leaves (determined with help of straight metre rule), weights of shoots and roots (with laboratory scale balance), chlorophyll content of leaves (using SPAD- 502 Plus chlorophyll metre), number of leaves produced including their weight, sweetness (Brix). The data obtained from these measurements was subjected to one-way analysis of variance (ANOVA) Post Hoc Tests by Duncan in SPSS version 24.0.

\section{RESULTS}

\section{Impact on soil $\mathbf{p H}$ and $\mathrm{EC}$}

Both biochar types stimulated increases in both $\mathrm{pH}$ and EC with or without NPK fertiliser. In fact, addition of NPK- biochar fertiliser combinations didn't have any effect on soil $\mathrm{pH}$ in comparison to when the biochar fertilisers were used alone. CLB application led to the highest increases in $\mathrm{pH}$ while the highest increases in EC were stimulated by NPOM. Soil pH was increased by 1.8 units when CLB was added alone against 1.6 units' increment that the combination with NPK triggered. NPOM and NPOM + NPK fertiliser combination increased the soil $\mathrm{pH}$ by the same margin of 1.2 units. Applying NPK fertiliser alone had an acidifying effect reducing soil $\mathrm{pH}$ by 0.4 units while the control had no noticeable effect on the soil $\mathrm{pH}$. With regards to soil EC, Combined application of biochar organic fertilisers with NPK had a positive effect on soil EC. For example, NPOM + NPK fertiliser combination stimulated a nine-fold increment in soil EC against the sevenfold stirred by NPOM. The same observation was noted with CLB + NPK fertiliser combination and CLB which stimulated fivefold and threefold increases respectively.

\section{Impact on available phosphorus}

Synchronizing the application of CLB with NPK fertiliser had a positive effect on the available phosphorus i.e. CLB + NPK fertiliser combination triggered a higher increase in available phosphorus which was fourfold more than when CLB was added alone. Conversely however, the combined application of NPK fertiliser and NPOM elicited a negative response in the soil EC i.e. soil amended with NPOM + NPK fertiliser combination experienced a twofold decrease in soil EC in comparison to when NPOM was used alone. There was no noticeable difference in the ECs of the control non-amended soil and NPK amended soil.

\section{Impact on exchangeable cations}

The concentrations of potassium in all the treatments plunged with the losses in CLB amended soils comparable to those in the biochar non-amended soils. The changes in soil calcium concentrations were varying and without a clear trend. For example, increases in calcium concentrations were observed in soils amended with NPOM, CLB and CLB + NPK whereas the other amendments caused losses in calcium ions. Both sodium and Magnesium concentrations plunged in all soils except the observed increase in NPOM + NPK fertiliser amended soil.

\section{Impact on soil carbon, organic matter and nitrogen}

Both biochar organic fertilisers increased the soil carbon (C) concentrations with CLB and NPOM stimulating five and nine fold increases respectively. There was no noticeable difference in carbon concentrations in non-amended and NPK alone amended soils. The organic matter (O.M) concentration of the soil increased by six and ten folds upon the addition of CLB and NPOM 
Table 1. Chemical Properties of Biochars

\begin{tabular}{|c|c|c|c|c|c|c|c|c|c|c|c|}
\hline \multirow[t]{2}{*}{ Treatment } & \multirow[t]{2}{*}{$\begin{array}{c}\mathrm{pH} \\
(1: 5)\end{array}$} & \multirow[t]{2}{*}{$\begin{array}{c}\mathrm{EC} \\
\left(\mathrm{ds} \mathrm{m}^{-1}\right)\end{array}$} & \multirow[t]{2}{*}{$\begin{array}{l}\text { Avail. P } \\
\left(\mathrm{mg} \mathrm{kg}^{-1}\right)\end{array}$} & \multicolumn{2}{|c|}{$\begin{array}{c}\text { Elemental content } \\
(\%)\end{array}$} & \multirow{2}{*}{$\begin{array}{l}\mathrm{OM} \\
(\%)\end{array}$} & \multirow{2}{*}{$\begin{array}{l}\mathrm{C} / \mathrm{N} \\
\text { ratio }\end{array}$} & \multirow[t]{2}{*}{$\mathrm{K}^{+}$} & $\mathrm{Ca}^{2+}$ & \multirow{2}{*}{$\frac{\mathrm{Mg}^{2+}}{\left(\mathrm{kg}^{-1}\right)}$} & \multirow[t]{2}{*}{$\mathrm{Na}^{+}$} \\
\hline & & & & $\mathrm{C}$ & $\mathrm{N}$ & & & & $\left(\mathrm{cmolc} \mathrm{kg}^{-1}\right)$ & & \\
\hline CLB & $7.2 \pm 0.0$ & $32.1 \pm 2.4$ & $190.0 \pm 7.0$ & $39.2 \pm 5.0$ & $2.7 \pm 0.1$ & 67.5 & 14.5 & $0.16 \pm 0.00$ & $0.35 \pm 0.05$ & $0.11 \pm 0.00$ & $0.01 \pm 0.00$ \\
\hline NPOM & $7.4 \pm 0.0$ & $11.4 \pm 0.4$ & $90 \pm 5.0$ & $50.4 \pm 0.9$ & $5.2 \pm 0.3$ & 86.8 & 9.6 & $0.28 \pm 0.04$ & $0.65 \pm 0.22$ & $0.29 \pm 0.01$ & $0.06 \pm 0.04$ \\
\hline
\end{tabular}

Abbreviations: EC, Electrical conductivity; Avail. P, Available phosphorus; OM, Organic matter; C, Carbon; N, Nitrogen; Ex. cations, Exchangeable cation

Table 2. Initial Soil Chemical Properties

\begin{tabular}{|c|c|c|c|c|c|c|c|c|c|c|c|}
\hline \multirow[t]{2}{*}{ Treatment } & \multirow[t]{2}{*}{$\begin{array}{c}\mathrm{pH} \\
(1: 5)\end{array}$} & \multirow[t]{2}{*}{$\begin{array}{c}\mathrm{EC} \\
\left(\mathrm{ds} \mathrm{m}^{-1}\right)\end{array}$} & \multirow[t]{2}{*}{$\begin{array}{l}\text { Avail. P } \\
\left(\mathrm{mg} \mathrm{kg}^{-1}\right)\end{array}$} & \multicolumn{2}{|c|}{$\begin{array}{c}\text { Elemental content } \\
(\%)\end{array}$} & \multirow{2}{*}{$\begin{array}{l}\mathrm{OM} \\
(\%)\end{array}$} & \multirow{2}{*}{$\begin{array}{l}\mathrm{C} / \mathrm{N} \\
\text { ratio }\end{array}$} & \multicolumn{4}{|c|}{$\begin{array}{l}\text { Ex. Cations } \\
\left(\mathrm{cmol}_{\mathrm{c}} \mathrm{kg}^{-1}\right)\end{array}$} \\
\hline & & & & $\mathrm{C}$ & $\mathrm{N}$ & & & $\mathrm{K}^{+}$ & $\mathrm{Ca}^{2^{+}}$ & $\mathrm{Mg}^{2+}$ & $\mathrm{Na}^{+}$ \\
\hline Soil & $6.4 \pm 0.0$ & $0.16 \pm 0.01$ & $12.3 \pm 1.04$ & $0.07 \pm 0.01$ & $0.06 \pm 0.00$ & 0.11 & 1.15 & $0.18 \pm 0.02$ & $6.6 \pm 0.3$ & $11.0 \pm 0.5$ & $0.21 \pm 0.05$ \\
\hline
\end{tabular}

Table 3. Final Chemical Properties

\begin{tabular}{|c|c|c|c|c|c|c|c|c|c|c|c|}
\hline \multirow[t]{2}{*}{ Treatment } & \multirow{2}{*}{$\begin{array}{l}\mathrm{pH} \\
(1: 5)\end{array}$} & \multirow{2}{*}{$\begin{array}{c}\text { EC } \\
\left(\mathrm{ds} \mathrm{m}^{-1}\right)\end{array}$} & \multirow{2}{*}{$\begin{array}{l}\text { Avail. P } \\
\left(\mathrm{mg} \mathrm{kg}^{-1}\right)\end{array}$} & \multicolumn{2}{|c|}{$\begin{array}{c}\text { Elemental content } \\
(\%)\end{array}$} & \multirow{2}{*}{$\begin{array}{l}\mathrm{OM} \\
(\%)\end{array}$} & \multirow{2}{*}{$\begin{array}{r}\mathrm{C} / \mathrm{N} \\
\text { ratio }\end{array}$} & \multicolumn{4}{|c|}{$\begin{array}{l}\text { Ex. Cations } \\
\left(\mathrm{cmol}_{\mathrm{c}} \mathrm{kg}^{-1}\right)\end{array}$} \\
\hline & & & & $\mathrm{C}$ & $\mathrm{N}$ & & & $\mathrm{K}^{+}$ & $\mathrm{Ca}^{2+}$ & $\mathrm{Mg}^{2+}$ & $\mathrm{Na}^{+}$ \\
\hline Control & $6.5 \pm 0.2$ & $0.15 \pm 0.04$ & $34.2 \pm 3.4$ & $0.05 \pm 0.01$ & $0.03 \pm 0.01$ & 0.09 & 1.61 & $0.08 \pm 0.01$ & $5.9 \pm 0.3$ & $2.1 \pm 0.1$ & $0.07 \pm 0.02$ \\
\hline $\mathrm{N}-\mathrm{P}-\mathrm{K}$ & $6.0 \pm 0.2$ & $48 \pm 0.00$ & $34.2 \pm 1.7$ & $0.09 \pm 0.07$ & $0.07 \pm 0.02$ & 0 . & 1.35 & $0.11 \pm 0.01$ & $6.0 \pm 0.1$ & $2.2 \pm 0.0$ & $0.08 \pm 0.00$ \\
\hline CLB & $8.2 \pm 0.1$ & $0.50 \pm 0.07$ & $272.2 \pm 25.4$ & $0.35 \pm 0.09$ & $0.05 \pm 0.00$ & 0.60 & 6.57 & $0.06 \pm 0.01$ & $7.2 \pm 0.1$ & $2.5 \pm 0.0$ & $0.17 \pm 0.07$ \\
\hline $\mathrm{CLB}+\mathrm{NPK}$ & $8.0 \pm 0.1$ & $0.87 \pm 0.13$ & $325.0 \pm 22.8$ & $0.39 \pm 0.03$ & $0.07 \pm 0.00$ & 0.67 & 5.80 & $0.08 \pm 0.02$ & $8.1 \pm 0.7$ & $2.8 \pm 0.3$ & $0.19 \pm 0.04$ \\
\hline NPOM & $7.6 \pm 0.1$ & $1.18 \pm 0.21$ & $174.2 \pm 35.0$ & $0.60 \pm 0.14$ & $0.09 \pm 0.00$ & 1.03 & 6.77 & $0.12 \pm 0.02$ & $7.2 \pm 0.5$ & $2.5 \pm 0.0$ & $0.05 \pm 0.01$ \\
\hline $\mathrm{NPOM}+\mathrm{NPK}$ & $7.6 \pm 0.1$ & $1.45 \pm 0.39$ & $143.7 \pm 15.8$ & $0.63 \pm 0.04$ & $0.09 \pm 0.02$ & 1.08 & 6.58 & $0.16 \pm 0.01$ & $6.1 \pm 0.1$ & $2.3 \pm 0.1$ & $0.39 \pm 0.03$ \\
\hline
\end{tabular}

Abbreviations: EC, Electrical conductivity; Avail. P, Available phosphorus; OM, Organic matter; C, Carbon; N, Nitrogen; Ex. cations,

Exchangeable cation

Table 4. Leek growth and agronomic parameters used for the assessment

\begin{tabular}{|c|c|c|c|c|c|c|c|c|}
\hline \multirow{3}{*}{ Treatment } & \multicolumn{2}{|c|}{ Fresh Weight } & \multirow{2}{*}{ Leaf length } & \multirow{2}{*}{ Leaf width } & \multirow{3}{*}{$\begin{array}{c}\text { Number of } \\
\text { leaves } \\
\text { (per plant) }\end{array}$} & \multirow{3}{*}{$\begin{array}{c}\text { Weight per } \\
\text { leaf } \\
\text { (g/ea) }\end{array}$} & \multirow{3}{*}{$\begin{array}{c}\text { Sweetness } \\
\text { (Brix) }\end{array}$} & \multirow{3}{*}{$\begin{array}{c}\text { Chlorophyl } \\
\text { (SPAD) }\end{array}$} \\
\hline & Shoot & Root & & & & & & \\
\hline & \multicolumn{2}{|c|}{ (g) } & \multicolumn{2}{|c|}{$(\mathrm{cm})$} & & & & \\
\hline Control & $8.7 \pm 2.2^{\mathrm{a}}$ & $10.7 \pm 3.0^{\mathrm{b}}$ & $24.9 \pm 2.3^{\mathrm{b}}$ & $0.16 \pm 0.05^{\mathrm{a}}$ & $118.5 \pm 18.1^{a}$ & $0.07 \pm 0.01^{\mathrm{a}}$ & $2.9 \pm 0.5^{\mathrm{a}}$ & $11.2 \pm 2.8^{\mathrm{a}}$ \\
\hline $\mathrm{N}-\mathrm{P}-\mathrm{K}$ & $9.6 \pm 3.2^{\mathrm{a}}$ & $6.4 \pm 2.6^{a}$ & $21.0 \pm 3.2^{\mathrm{a}}$ & $0.18 \pm 0.04^{\mathrm{a}}$ & $126.1 \pm 27.9^{\mathrm{a}}$ & $0.07 \pm 0.01^{\mathrm{a}}$ & $3.9 \pm 0.7^{\mathrm{a}}$ & $12.9 \pm 3.9^{\mathrm{a}}$ \\
\hline CLB & $11.0 \pm 0.6^{\mathrm{a}}$ & $11.2 \pm 2.3^{\mathrm{b}}$ & $26.1 \pm 1.1^{\mathrm{b}}$ & $0.16 \pm 0.04^{a}$ & $119.0 \pm 6.5^{\mathrm{a}}$ & $0.09 \pm 0.01^{\mathrm{a}}$ & $2.8 \pm 0.7^{\mathrm{a}}$ & $26.8 \pm 4.0^{\mathrm{b}}$ \\
\hline $\mathrm{CLB}+\mathrm{NPK}$ & $26.1 \pm 0.5^{c}$ & $17.9 \pm 0.5^{c}$ & $32.5 \pm 2.1^{c}$ & $0.23 \pm 0.05^{\mathrm{a}}$ & $152.6 \pm 19.5^{c}$ & $0.17 \pm 0.02^{c}$ & $3.2 \pm 0.5^{\mathrm{a}}$ & $50.1 \pm 1.4^{c}$ \\
\hline NPOM & $22.0 \pm 2.4^{\mathrm{b}}$ & $13.1 \pm 0.9^{b}$ & $30.3 \pm 1.5^{c}$ & $0.23 \pm 0.05^{\mathrm{a}}$ & $153.3 \pm 8.3^{\mathrm{ab}}$ & $0.14 \pm 0.01^{\mathrm{b}}$ & $3.0 \pm 0.3^{\mathrm{a}}$ & $46.2 \pm 9.7^{\circ}$ \\
\hline NPOM+NPK & $11.3 \pm 3.3^{\mathrm{a}}$ & $5.7 \pm 1.9^{\mathrm{a}}$ & $26.6 \pm 1.3^{\mathrm{b}}$ & $0.20 \pm 0.00^{\mathrm{a}}$ & $125.0 \pm 18.7^{\mathrm{ab}}$ & $0.09 \pm 0.02^{\mathrm{a}}$ & $3.8 \pm 0.6^{a}$ & $42.6 \pm 8.1^{c}$ \\
\hline
\end{tabular}

Values represent by means \pm SD, One-way analysis of variance, ANOVA, Post Hoc Tests by Duncan in SPSS version 24.0. 
respectively whereas that of the control decreased. There was a slight increase in the O.M concentration of NPK amended soil. The soil nitrogen concentration of the control and CLB decreased while the rest of the treatments stimulated slight increases in the concentration of soil nitrogen.

\section{Impact on Leek growth and yield}

The impact of the synchronized application of NPK and biochar organic fertilisers varied between the two organic fertiliser types. For example, combined addition of CLB and NPK fertiliser exhibited synergistic effects for most of the growth parameters assessed compared with when CLB was used alone. Contrarily, application of NPK fertiliser to the soil amended with NPOM mainly had negative effects in comparison with NPOM applied alone as indicated in table 4 above. The best growth and yield results of leek were obtained from the combined application of NPK and CLB.

\section{DISCUSSION}

\section{Observed trends in Leek growth and yield}

The observed increase in leek yield upon addition of CLB biochar organic fertiliser and NPK was in agreement with the observations made by Steiner et al. (2007) in rice and sorghum where charcoal with NPK fertiliser were applied to an acidic, highly weathered tropical soil. Also, Van Zwieten et al. 2010 noted enhanced crop performance when paper mill waste biochar was applied together with NPK fertiliser. This was attributed to the liming effect of biochar organic fertilisers. Major et al. (2009) indicated that biochars adsorb both anions and cations which may reduce leaching of applied NPK making nutrients available to the growing plants, consequently improving yields. Tan et al. 2018 also revealed that combined that combined application of biochar with organic and or inorganic fertilisers increased peanut yield and nitrogen uptake attributing this increased yield to increased availability of trace elementssupplied by the organic fertilisers. Therefore, the higher yields observed with the combination of CLB and NPK were possibly a combination of improved soil conditions created by the biochar organic fertiliser and the increased nutrient supply readily availed by the NPK fertiliser.

Biochars and non-pyrolysed organic materials have contrasting effects on the growth of cropswith the effects dependent on their chemical characteristics (Bonanomi et al., 2017). Studies by Dorrepaal et al. (2007), LopezIglesias et al. (2014) and Meiners (2014) elucidated the inhibition of root development by undecomposed litter organic materials in the natural ecosystems with Hodge et al. (2000) attributing the crop growth inhibition by undecomposed litter on microbial nitrogen immobilisation at high $\mathrm{C} / \mathrm{N}$ ratios while Bonanomi et al. (2011) attributed it to the phytotoxicity of allelopathic compounds. However, all the aforementioned assertions can't explain the trends observed with NPOM. This is because NPOM (with $80 \%$ of non-charred biomass) itself caused significant yield increases compared to
NPK and the control experiments but the yields decreased when it was combined with NPK. One of the possible explanation for this anomaly is the adsorption of the applied NPK fertiliser into the biochar pores thereby making it inaccessible by the plant roots.

\section{Observed Changes in Soil Chemical Properties}

The increases in soil $\mathrm{pH}$ and EC upon biochar application have been indicated by a number of studies including Chintala et al. (2013), Shen et al. (2016), Trupiano et al. (2017) and others. The liming power of biochar has been indicated as the main factor driving $\mathrm{pH}$ increases (Trupiano et al., 2017) while the increase in EC is due to exchange of electrons between the soil solution and the added biochar (Joseph et al., 2010). The increase in EC observed upon the addition of NPK fertiliser can be ascribed to the dissociation of the fertiliser in the soil solution and the consequential exchange of the dissociated ions between the soil clay mineral surfaces and the soil solution. Therefore, the higher soil EC values observed with the combinations of NPK and the biochar organic fertilisers can be the compounding effect of ion and electron exchanges triggered by both NPK and biochar organic fertilisers. Some of the reasons for the increased available phosphorus may include, the raised soil $\mathrm{pH}$ with consequential release of phosphorus into the soil solution (Shen et al., 2016) and the supply of phosphorus into the soil by both biochar organic fertilisers and NPK (Deluca et al., 2009). The NPK amended soil had low phosphorus concentrations possibly because the phosphorus was fixed in the mild acidic conditions (Stevenson and Cole, 1999).

The aromatic biochars produced at temperatures above $550^{\circ} \mathrm{C}$ have been talked about as the most suitable for carbon storage (Novak and Busscher et al., 2013). The reason behind their suitability is the recalcitrant nature of the biochars making it hard for microbes to break them down (Zimmerman et al., 2011). This can be a possible explanation why these biochar organic fertilisers elicited increases in soil organic carbon. The adsorption and protection of organic matter from microbial decomposition by the biochar pores (Cornelissen et al., 2005; Sobek et al., 2009) may account for the observed increases in soil organic matter. For both organic carbon and organic matter, synchronizing the addition of NPK fertiliser with biochar organic fertilisers didn't produce any noticeable difference possibly because chemical fertilisers are not building blocks of soil carbon and therefore their presence couldn't influence soil carbon concentrations. The slight increase in soil organic matter observed with NPK fertiliser could be because of decomposing leek roots and or fallen leaves.

\section{CONCLUSION}

Not many studies have explored the effects of synchronizing the applications of mixed biochar organic fertilisers and NPK but the results in this study have displayed both positive, negative and no effects. Therefore, before adding NPK fertiliser to the soil amended with 
biochar organic fertiliser, it's better to first understand the interactions between the two and whether or not any synergism exists. This can be predicted from the chemical properties of the non-pyrolysed materials blended with biochars to produce the biochar organic fertilisers. For this study, organic fertiliser produced from a blend of compost and biochar exhibited synergistic effects in crop growth promotion and amelioration of soil chemical properties.

\section{AUTHOR CONTRIBUTIONS}

Deogratius Luyima, Jae-Han Lee, Ji-Young An, OhSeok Kwon, Sang-Yeon Park, Su-Jin Lee, and SeongYong Park carried out analysis and interpretation of data. Yoshiyuki SHINOGI verified the data. Taek-Keun $\mathrm{OH}$ and Kee Woong Park supervised the project and wrote the paper. All authors commented on the manuscript.

\section{ACKNOWLEDGMENT}

This work was supported by Korea Institute of Planning and Evaluation for Technology in Food, Agriculture, Forestry and Fisheries (IPET) through "Agri-Bioindustry Technology Development Program", funded by Ministry of Agriculture, Food, and Rural Affairs (MAFRA) (Project No. 315026-3).

\section{REFERENCES}

Akhtar, S. S., M. N. Andersen, M. Naveed, Z. A. Zahir and F. Liu 2015. Interactive effect of biochar and plant growth-promoting bacterial endophytes on ameliorating salinity stress in maize. Functional Plant Biology, 42(8): 770

Bol, R. 2000 Tracing dung-derived carbon in temperate grassland using 13C natural abundance measurements. Soil Biology and Biochemistry, 32: 1337-43

Bonanomi, G., G. Incerti, E. Barile, M. Capodilupo, V. Antignani, and A. Mingo 2011 Phytotoxicity, not nitrogen immobilization, explains plant litter inhibitory effects: evidence from solid-state 13C NMR spectroscopy. New Phytol. 191: 1018-1030

Bonanomi, G., F. Ippolito, G. Cesarano, B. Nanni, N. Lombardi, A. Rita, and F. Scala 2017 Biochar as Plant Growth Promoter: Better Off Alone or Mixed with Organic Amendments?. Frontiers in Plant Science, 15(8): 1750 doi: 10.3389/ fpls.2017.01570

Chintala, R., J. Mollinedo, T. E. Schumacher, D. D. Malo and J. L. Julson 2013 Effect of biochar on chemical properties of acidic soil. Archives of Agronomy and Soil Science, 60(3): 393-404

Cornelissen, G., O. Gustafsson, T. D. Bucheli, M. T. O. Jonker, A. A. Koelmans, and P. C. M. Van Noort 2005 Extensive sorption of organic compounds to black carbon, coal, and kerogen in sediments and soils: mechanisms and consequences for distribution, bioaccumulation, and biodegradation. Environmental Science \& Technology, 39: 6881-6895

Deluca, T. H., M. D. MacKenzie, and M. J. Gundale 2009 Biochar effects on soil nutrient transformations. In: J. Lehmann, S. Joseph (Eds.), Biochar for Environmental Management: Science and Technology, Earth scan, London, 251-270

Ding, Y., Y. Liu, S. Liu, Z. Li, X. Tan, X. Huang and B. Zheng 2016 Biochar to improve soil fertility. A review. Agronomy for Sustainable Development, 36: 36

Dorrepaal, E., J. H. Cornelissen and R. Aerts 2007 Changing leaf litter feedbacks on plant production across contrasting sub-arctic peatland species and growth forms. Oecologia, 151: 251-261

FAO. 2006a. Livestock's long shadow: environmental issues and options. FAO, Rome

Gruhn, P., F. Goletti, and M. Yudelman 2000 Integrated nutrient management, soil fertility, and sustainable agriculture: current issues and future challenges. In: Food, Agriculture, and the Environment Discussion Paper International Food Policy Research Institute: USA

Han, K. H., Y. S. Zhang, K. H. Jung, H. R. Cho, M. J. Seo and Y. K. Son 2016 Statistically estimated storage potential of organic carbon by its association with clay content for Korean upland subsoil. Korean Journal of Agricultural Science, 43: 353-359

Hodge, A., D. Robinson and A. Fitter 2000 Are microorganisms more effective than plants at competing for nitrogen?. Trends in Plant Science, 5(7): 304-308

Hua, L., W. Wu, Y. Liu, M. B. McBride and Y. Chen 2009 Reduction of nitrogen loss and $\mathrm{Cu}$ and $\mathrm{Zn}$ mobility during sludge composting with bamboo charcoal amendment. Environmental Science and Pollution Research, 16(1): 1-9

Jien, S. H and C. S. Wang 2013 Effects of biochar on soil properties and erosion potential in a highly weathered soil. CATENA, 110: $225-233$

Jones, D. L., P. Cross, P. J. A. Withers, T. H. DeLuca, D. A. Robinson, R. S. Quilliam and G. Edwards-Jones 2013 REVIEW Nutrient stripping: the global disparity between food security and soil nutrient stocks. Journal of Applied Ecology, 50(4): 851-862

Joseph, S. D., M. Camps-Arbestain, Y. Lin, P. Munroe, C. H. Chia, J. Hook and J. E. Amonette 2010 An investigation into the reactions of biochar in soil. Australian Journal of Soil Research, $\mathbf{4 8}(7): 501$

Kim, P., D. Hensley and N. Labbé 2014 Nutrient release from switch grass-derived biochar pellets embedded with fertilizers. Geoderma, 232-234: 341-351

Lee, H. S. 2013 Effects of biochar on enzyme activities and greenhouse gas in agricultural soils. Master's Degree thesis, Yonsei Univ., Seoul

Lee, S. B., J. E. Lim, Y. J. Lee, J. K. Sung, D. B. Lee and S. Y. Hong 2016 Analysis of components and applications of major crop models for nutrient management in agricultural land. Korean Journal of Agricultural Science, 43: 537-546

Lehmann, J. and S. Joseph 2015 Biochar for environmental management: An introduction, in biochar for environmental management: Science, Technology and Implementation. Earthscan, London. pp. 1-11

Lin, G., H. Yang, J. Hu, Y. Luo, J. Shao, X. Wang, and H. Chen 2016 Effects of the physicochemical properties of biochar and soil on moisture sorption. Journal of Renewable and Sustainable Energy, 8(6): 064702

Liu, E., Y. Changrong, M. Xurong, H. Wenqing, H. B. So, D. Linping, L. Qin, L. Shuang, and F. Tinglu. 2010. Long term effect of chemical fertilizer, straw, and manure on soil chemical and biological properties in north-west China. Geoderma, 150: 173-80

Liu, J., H. Schulz, S. Brandl, H. Miehtke, B. Huwe, and B. Glaser 2012 Short-term effect of biochar and compost on soil fertility and water status of a Dystric Cambisol in NE Germany under field conditions. Journal of Plant Nutrition and Soil Science, 175: $698-707$

Lopez-Iglesias, B., M. Olmo, A. Gallardo and R. Villar 2014 Short-term effects of litter from 21 woody species on plant growth and root development. Plant Soil, 381: 177-191

Major, J., C. Steiner, A. Downie and J. Lehmann 2009 Biochar effects on nutrient leaching. In: Lehmann J, Joseph S (eds) Biochar for Environmental Management. Earth scan Publications Ltd. ISBN: 9781844076581, pp. 271-287

Malghani, S., G. Gleixner and S. E. Trumbore 2013 Chars produced by slow pyrolysis and hydrothermal carbonization vary in carbon sequestration potential and greenhouse gases emissions. Soil Biology and Biochemistry, 62: 137-146

Meiners, S. J. 2014. Functional correlates of allelopathic potential in a successional plant community. Plant Ecol. 215: 661-672

Müller, A. 2009 Climate change mitigation: unleashing the potential agriculture. Presentation made to the UNFCCC Ad Hoc working Group on Long-Term Cooperative Action, Bonn, 
Germany, 4th April 2009

Naeem, M.A., M. Khalid, M. Aon, G. Abbas, M. Amjad, B. Murtaza, W. D. Khan and N. Ahmad 2018 Combined application of biochar with compost and fertilizer improves soil properties and grain yield of maize, Journal of Plant Nutrition, 41: 112-122

Novak, J. M., W. J. Busscher, D. L. Laird, M. Ahmedna, D. W. Watts and M. A. S. Niandou 2009 Impact of Biochar Amendment on Fertility of a South eastern Coastal Plain Soil. Soil Science, 174(2): 105-112

Oh, T. K. J. H. Lee, S. H. Kim and H. C. Lee 2017 Effect of biochar application on growth of Chinese cabbage (Brassica chinensis). Korean Journal of Agricultural Science, 44: 359-365

Oh, T. K. and Y. Shinogi 2013 Characterization of the pyrolytic solid derived from used disposable diapers. Environmental Technology, 34(24): 3153-3160

Oh, T. K., Y. Shinogi, S. J. Lee and B. S. Choi 2014 Utilization of biochar impregnated with anaerobically digested slurry as slowrelease fertilizer. J. Plant Nutr. Soil Sci., 177: 97-103

Palm, C. A., C. N. Gachengo, R. J. Delve, G. Cadisch, and K. E. Giller 2001 Organic inputs for soil fertility management in tropical agroecosystems: application of an organic resource database. Agriculture, Ecosystem and Environment, 83: 27-42

Ro, K. S., K. B. Cantrell and P. G. Hunt 2010 High-temperature pyrolysis of blended animal manures for producing renewable energy and value-added biochar. Ind. Eng. Chem. Res. 49(20): 10125-10131

Shahid, S. A., F. K. Taha, S. Ismail, A. Dakheel and M. Abdelfattah 2011 Turning Adversity into an Advantage for Food Security Through Improving Soil Quality and Providing Production Systems for Marginal Saline Lands: ICBA Perspectives and Approach. Sustainable Agricultural Development, 43-67

Shen, Q., M. Hedley, M. C. Arbestain and M. U. Kirschbaum 2016 Can biochar increase the bioavailability of phosphorus?
Journal of Soil Science and Plant Nutrition, 16(2): 268-286

Sobek, A., N. Stamm and T. D. Bucheli 2009 Sorption of phenyl urea herbicides to black carbon. Environmental Science \& Technology, 43(21): 8147-8152

Sohi, S. P. 2012 Carbon storage with benefits. Science, 338(6110): 1034-1035

Steiner, C., W. G. Teixeira, J. Lehmann, T. Nehls, J. L. Vasconcelos de Macêdo, W. E. H. Blum and W. Zech 2007 Long term effects of manure, charcoal and mineral fertilization on crop production and fertility on a highly weathered Central Amazonian upland soil. Plant Soil, 291: 275-290

Stevenson, F. J and M. A. Cole 1999. Cycles of Soils: Carbon, Nitrogen, Phosphorus, Sulfur, Micronutrients, second edition, John Wiley and Sons, Inc, New York, NY

Tan, G., H. Wang, N. Xu, H. Liu and L. Zhai 2018. Biochar amendment with fertilizers increases peanut $\mathrm{N}$ uptake, alleviates soil $\mathrm{N}_{2} \mathrm{O}$ emissions without affecting $\mathrm{NH}_{3}$ volatilization in field experiments. Environmental Science and Pollution Research, 25(9): 8817-8826

Trupiano, D., C. Cocozza, S. Baronti, C. Amendola, F. P. Vaccari, G. Lustrato and G. S. Scippa 2017 The Effects of Biochar and Its Combination with Compost on Lettuce (Lactuca sativa L.) Growth, Soil Properties, and Soil Microbial Activity and Abundance. International Journal of Agronomy, 2017: 1-12

Van Zwieten, L., S. Kimber, S. Morris, K. Y. Chan, A. Downie, J. Rust and A. Cowie 2009 Effects of biochar from slow pyrolysis of paper mill waste on agronomic performance and soil fertility. Plant and Soil, 327(1-2): 235-246

Zimmerman, A. R., B. Gao and M. Y. Ahn 2011 Positive and negative carbon mineralization priming effects among a variety of biochar-amended soils. Soil Biology and Biochemistry, 43(6): 1169-1179 